\title{
Assisted reproductive technologies (ART) in Latin America: The Latin American Registry, 2011
}

Fernando Zegers-Hochschild, MD ${ }^{1,2}$, Juan Enrique Schwarze ${ }^{3}$, MD, MSc, Javier A. Crosby ${ }^{1}$, PhD, Carolina Musri ${ }^{1}$, $\mathrm{BQ}$, and Maria do Carmo Borges de Souza MD, $\mathrm{PhD}^{4}$

${ }^{1}$ Unit of Reproductive Medicine Clínica las Condes, Chile

2 Program of Ethics and Public Policies in Human Reproduction, University Diego Portales, Chile

${ }^{3}$ Clínica Monteblanco, Chile

${ }^{4}$ Fertipraxis- Centro de Reprodução Humana- RJ, Brasil

\section{ABSTRACT}

Background: This 23rd report represents the results of ART procedures performed during 2011 by 145 centers from 12 countries in Latin America. This is the second time the data was individually collected in a case-by-case modality.

Methods: All centers reported their ART procedures electronically and their data was accepted after consistency checks were performed and an accreditation team certified the institution. A total of 41,232 procedures included 28,065 initiated fresh homologous ART cycles consisting of 4,089 in vitro fertilization (IVF) cycles; 23,976 Intra cytoplasmic sperm injection (ICSI); 6,909 frozen embryo transfers (FET) and 6,258 oocyte donations (OD), plus 14 cases of GIFT, which are not described in this report.

Results: Thirty eight percent of ET in IVF/ICSI cycles were performed in women age 35-39 years, while 25\% included women $\geq 40$. The delivery rate (DR) per ovum pick-up (OPU) in ICSI and IVF cycles were $20.7 \%$ and $23.9 \%$, respectively. The multiple delivery rate in IVF/ICSI cycles grouped together, was $22.3 \%$ ( $21.0 \%$ twins and $1.3 \%$ triples). When $\geq 2$ embryos were transferred, neither the CPR nor the proportion of twins increased significantly. However, the proportion of triplet increased significantly when $\geq 3$ embryos were transferred. In OD cycles, twin and triplet deliveries were $28.5 \%$ and $1.6 \%$, respectively. In FET cycles, twin and triplet deliveries were $17.8 \%$ and $1.4 \%$, respectively. Multiple deliveries were associated with a significant increase in preterm delivery and perinatal mortality. In cases of elective transfers, the DR was $19.8 \%$ with eSET and $35.8 \%$ with eDET. In women aged $\leq 34$ years, DR with eSET was $29.6 \%$ and $39.5 \%$ with eDET. Furthermore, in OD cycles, the DR with eSET was $25.0 \%$, and $38.1 \%$ with eDET.

Conclusions: Overall, delivery rates are acceptable and comparable to most developed countries in the world. However, Latin American countries need to enforce the reduction in the number of embryos transferred in IVF/ICSI and OD cycles, in order to decrease the rate of multiple births and therefore decrease the corresponding perinatal complications.

\section{RESUMEN}

Introducción: Presentamos la vigésima tercera edición del Registro Latinoamericano de Reproducción Asistida (RLA). Esta edición reporta los ciclos realizados por 145 centros en doce países, y corresponde al segundo reporte que registra información individual, también llamando "registro caso a caso".

Métodos: Todos los centros reportaron electrónicamente la información de ciclos de reproducción asistida iniciados en el año 2011; los datos fueron incorporados a la base de datos del RLA luego de ser confirmada su consistencia interna. Así, un total de 41,232 procedimientos fueron incluidos, que corresponden a 28,065 ciclos homólogos ( 4,089 ciclos iniciados de FIV y 23,976 ciclos iniciados de ICSI); 6,909 ciclos de FET y 6,258 ciclos OD; y 14 casos de GIFT, que no fueron incluidos en el presente reporte.

Resultados: Treinta y ocho por ciento de las TE en ciclos de FIV/ICSI fueron realizados en mujeres entre 35 y 39 años; y $25 \%$ fueron realizadas en mujeres de 40 y más años. Las tasas de parto por aspiración en ciclos de ICSI y FIV fueron $20.7 \%$ y $23.9 \%$, respectivamente; la frecuencia de parto múltiple fue $22.3 \%$ ( $21.0 \%$ dobles y $1.3 \%$ triples y mayores). Cuando se transfirió > 2 embriones, no hubo un aumento significativo ni en la tasa de parto ni en la frecuencia de parto gemelar doble. Sin embargo, la proporción de parto triple aumentó significativamente cuando se transfirió $\geq$ tres embriones. En ciclos con OD, la frecuencia de parto doble y triple fue $28.5 \%$ and $1.6 \%$, respectivamente. En ciclos de FET, la frecuencia de parto doble y triple fue $17.8 \%$ y $1.4 \%$, respectivamente. Los partos múltiples se asociaron con un aumento significativo en la prematurez y mortalidad perinatal. En ciclos FIV/ ICSI, la tasa de parto al transferir electivamente un embrión fue $19.8 \%$, y al transferir dos embriones $35.8 \%$. En mujeres con 34 y menos años, estas tasas fueron $29.6 \%$ y $39.5 \%$, respectivamente. Y en ciclos de OD, estas tasas fueron $25.0 \%$ y $38.1 \%$, respectivamente.

Conclusiones: En general, las tasas de parto reportadas son comparables a las publicadas por países de Europa. Sin embargo, los centros deben extremar esfuerzos para disminuir el número de embriones transferidos, y así reducir la frecuencia de parto múltiple y las complicaciones perinatales derivadas. Es importante hacer esfuerzos por restringir las transferencias embrionarias a uno o dos embriones y con ello eliminar los riesgos derivados de la prematurez que acompaña a la multigestación de alto orden.

\section{RESUMO}

Objetivo: Este 230 relato representa os resultados de procedimentos de RA realizados em 2011 por 145 centros de 12 países na América Latina.

Métodos: Todos os centros registraram seus procedimentos eletronicamente e os dados foram aceitos após checagem de consistência, cada instituição certificada por acreditadores. Um total de 41.232 procedimentos incluíram 28.065 ciclos de RA homólogos iniciados, 'a fresco, consistindo de 4.089 ciclos de fertilização in vitro (FIV); 23.976 Intra injeção citoplasmática de espermatozóides (ICSI), 6.909 transferências de embriões congelados (FET) e 6.258 doações de ovócitos (OD), além de 14 casos de GIFT, que não estão descritos neste relatório. Resultados: Trinta e oito por cento das TE de FIV / ICSI ciclos foram realizadas em mulheres idade 35-39 anos, enquanto $25 \%$ incluíam mulheres $\geq 40$. A taxa de partos (DR) por aspiração (OPU) em ciclos de FIV e ICSI foi de 20,7\% e 23,9\%, respectivamente. A taxade partos múltiplos na FIV / ICSI agrupadas, foi de $22,3 \%$ ( $21,0 \%$ de duplos e 1,3\% triplos). Quando $\geq 2$ embriões foram transferidos, nem a taxa de gravidez clínica nem a proporção de gémeos aumentou significativamente. No entanto, a proporção de triplos aumentou significativamente quando $\geq 3$ embriões foram transferidos. Nos ciclos de OD, os partos únicos e de trigêmeos foram $28,5 \%$ e 1,6\%, respectivamente. Em ciclos FET, as taxas de únicos e de trigêmeos foram 17,8\% e 1,4\%, respectivamente. Múltiplos foram associados com um aumento significativo de parto prematuro e de mortalidade perinatal. Em casos de transferências eletivas, a taxa de partos foi de $19,8 \%$ com o eSET e $35,8 \%$ com eDET. Em mulheres $\leq 34$ anos, DR com o eSET foi de $29,6 \%$ e 
$39,5 \%$ com eDET. Além disso, em ciclos de OD, a DR com eSET foi de $25,0 \%$, e $38,1 \%$ com eDET.

Conclusões: No geral, as taxas de entrega são aceitáveis e comparáveis aos países mais desenvolvidos do mundo. No entanto, os países latino-americanos precisam cumprir a redução do número de embriões transferidos em FIV / ICSI e ciclos de OD, a fim de diminuir a taxa de nascimentos múltiplos e, portanto, diminuir as complicações perinatais correspondentes.

Conclusões: Em geral, as taxas de nascimentos são comparáveis aos países mais desenvolvidos. Todavia, a América latina deve reforçar a necessidade de transferir menor número de embriões nos ciclos de RA, a fim de prevenir nascimentos múltiplos e diminuir as consequentes complicações perinatais.

\section{INTRODUCTION}

This report corresponds to the twenty third edition of the Latin American Registry of Assisted Reproductive Technology (RLA). Previous reports, namely from 1990 through 1998, are available as printed copies; from 1999 through 2009 are available as PDF files, which can be freely downloaded from the web page of Red Latino Americana de Reproducción Asistida (REDLARA) at www.redlara.com. From 2010 onwards, the reports are published both in this journal, the official journal of REDLARA, and on-line.

The main objectives of RLA include: to register the number and characteristics of assisted reproductive techniques (ART) procedures performed in Latin America (LA); to register their outcomes, including controlled ovarian hyperstimulation, pregnancies and perinatal outcomes; to register the complications associated with ART procedures and the frequency and characteristics of congenital malformations; and to evaluate trends in multiple pregnancy and delivery, preterm birth, perinatal mortality and others.

\section{MATERIAL AND METHODS}

Data collection

One hundred and forty five centers from twelve countries (Annex I ) reported ART procedures performed from January through December 2011. ART procedures included are: IVF, ICSI, GIFT, OD (both fresh and frozen), FET, and PGD.

Data validation

The data provided by each centers is checked by RLA's central office for inconsistency; and any error or discrepancy is discussed with the center, and the data is rectified if necessary.

Limitations of data collection

Two are the limitations of the RLA. The first limitation is that some centers lack complete follow-up of each pregnancy. This is especially so in centers not associated with obstetric units. We estimate that missing data is in the order of $5 \%$ of pregnancies. The second limitation is that because registering is voluntary and having the center certified by an independent body is a condition to report, , some LA centers do not report their procedures to the RLA. We estimate that the RLA registers procedures performed by the vast majority of large institutions in Latin America.

\section{Statistical analysis}

Chi square test was used to analyze independence of categorical variables. When comparing two outcomes, the risk ratio (RR), and its corresponding $95 \%$ confidence interval $(95 \% \mathrm{CI})$ are presented. When multiple variable analyses were performed, i.e. logistic regression or lineal regression, the dependent variables were considered significant if the $\mathrm{p}$-value was less than 0.05 .

\section{RESULTS}

\section{Participating centers}

One hundred and forty five centers belonging to 12 countries reported 41,232 ART procedures performed during 2011 (Annex I). This represents eight more centers than those reporting in 2010. The new institutions correspond to one more institution in Argentina, Colombia, Brazil and Peru; and four in Mexico.

\section{Size of participating institutions}

The number of initiated cycles corresponds to the sum of initiated cycles of IVF/ICSI/GIFT, and embryo transfer cycles for both FET and OD. The average number of initiated cycles registered was 300. More than half of the centers registered less than 185 cycles, whereas only six centers registered more than one thousand cycles. The distribution of institutions according to the number of cycles registered is as follows: $28 \% \leq 100$ cycles; $35 \%$ between 100 and 250 cycles; $21 \%$ between 251 and 500 cycles; $12 \%$ between 500 and 1,000 cycles; and only 4\%, $\geq 1,000$ cycles.

\section{ART procedure and access}

The total number of ART procedures registered by the RLA was 41,232 . Of these, $46 \%(n=18,952)$ were reported by Brazil; $24 \%(n=9,857)$ by Argentina; and $13 \%(n=5,268)$ by Mexico (table 1 ).

Table 1. ART procedures and access in 2011

\begin{tabular}{lcccccccc}
\hline \multirow{2}{*}{ Country } & $\begin{array}{c}\text { Number } \\
\text { of } \\
\text { clinics }\end{array}$ & $\begin{array}{c}\text { IVF } \\
(*)\end{array}$ & $\begin{array}{c}\text { ICSI } \\
(*)\end{array}$ & FET & $\begin{array}{c}\text { OD } \\
(* *)\end{array}$ & Total & $\begin{array}{c}\text { Access } \\
(* * *)\end{array}$ \\
\hline $\begin{array}{l}\text { Argen- } \\
\text { tina }\end{array}$ & 25 & 647 & 5398 & 1591 & 2,221 & 9857 & 465 \\
\hline Brazil & 54 & 1156 & 12757 & 3745 & 1,294 & 18952 & 190 \\
\hline Chile & 7 & 161 & 1267 & 325 & 166 & 1919 & 223 \\
\hline Colombia & 9 & 317 & 401 & 127 & 262 & 1107 & 49 \\
\hline Ecuador & 5 & 79 & 347 & 85 & 159 & 670 & 89 \\
\hline $\begin{array}{l}\text { Guate- } \\
\text { mala }\end{array}$ & 1 & 35 & 56 & 8 & 13 & 112 & 16 \\
\hline Mexico & 29 & 1034 & 2349 & 700 & 1,185 & 5268 & 91 \\
\hline $\begin{array}{l}\text { Nicara- } \\
\text { gua }\end{array}$ & 1 & 56 & 30 & 0 & 3 & 89 & 31 \\
\hline Panama & 1 & 2 & 201 & 31 & 34 & 268 & 156 \\
\hline Peru & 5 & 274 & 723 & 148 & 683 & 1828 & 123 \\
\hline Uruguay & 2 & 14 & 246 & 40 & 58 & 358 & 209 \\
\hline $\begin{array}{l}\text { Vene- } \\
\text { zuela }\end{array}$ & 6 & 314 & 201 & 109 & 180 & 804 & 121 \\
\hline Total & 145 & 4,089 & 23,976 & 6,909 & 6,258 & 41,232 & 158 \\
\hline
\end{tabular}

include 14 cycles of GIFT/TOMI in Chile

$\left(^{*}\right)$ initiated cycles; $(* *)$ includes the transfer of fresh and frozen embryos ; $(* * *)$ number of cycles/million of women $15-45$ years

Out of 28,065 initiated autologous-cycles, 4,089 (15\%) corresponded to IVF, and $23,976(85 \%)$ to ICSI. One hundred and thirty two centers registered 6.909 FET cycles. And one hundred twenty eight clinics reported 6,258 OD cycles. In $60 \%$ of these cycles, the eggs were donated from exclusive donors, i.e. women that underwent controlled ovarian hyperstimulation (COS) and oocyte pick up with the only purpose of donating their oocytes; and $40 \%$ were egg-sharing, i.e. patients undergoing COS and oocyte pick-up, for an autologous treatment and simultaneously donated a proportion of their gametes to a third party.

Table 1 also shows access to ART procedures in LA, expressed as the total number of initiated cycles per million women aged 15 to 45 years.

\section{Pregnancies and deliveries}

Tables $2 \mathrm{a}$ and $2 \mathrm{~b}$ show the clinical pregnancy rate (CPR) and delivery rate (DR) per oocyte pick-up and embryo transfer of ART procedures performed in 2011. In the case of ICSI cycles, the overall CPR and DR per oocyte pick-up were $29.8 \%$ and $20.7 \%$, respectively. These rates were higher in the case of IVF cycles: $34.7 \%$ and $23.9 \%$, respectively (table 2a). In both instances, the difference reached statistical significance, however the lack of random distribution of subject in each treatment category, does not allow drawing scientifically sound conclusions. The RR for clinical pregnancy per OPU was 1. 24 (95\% CI 1.25-1.33); and the RR for delivery per OPU was 1.26 (95\% CI 1.16-1.36). 
In $\mathrm{OD}$ cycles, the clinical pregnancy rate and delivery rate were $51.9 \%$ and $37.1 \%$, respectively. In FET cycles, the clinical pregnancy rate and delivery rate were $35.2 \%$ and $23.6 .5 \%$, respectively. These rates were higher in FET when the oocytes were donated: $35.8 \%$ and $24.3 \%$, respectively (table $2 \mathrm{~b}$ ).

Table 2a. Clinical pregnancy rate and delivery rate IVF/ ICSI, 2011

\begin{tabular}{lccc}
\hline $\begin{array}{l}\text { ART } \\
\text { procedure }\end{array}$ & $\begin{array}{c}\text { Oocyte pick } \\
\text { up (OPU) }\end{array}$ & $\begin{array}{c}\text { Clinical } \\
\text { pregnancy } \\
\text { rate per OPU }\end{array}$ & $\begin{array}{c}\text { Delivery rate } \\
\text { per OPU }\end{array}$ \\
\hline ICSI & 22391 & $29.8 \%$ & $20.7 \%$ \\
\hline IVF & 3930 & $34.7 \%$ & $23.9 \%$ \\
\hline
\end{tabular}

Table 2b. Clinical pregnancy rate and delivery rate $O D$, FET, FET(OD); 2011

\begin{tabular}{lccc}
\hline $\begin{array}{l}\text { ART } \\
\text { procedure }\end{array}$ & $\begin{array}{c}\text { Embryo } \\
\text { transfer (ET) }\end{array}$ & $\begin{array}{c}\text { Clinical } \\
\text { pregnancy } \\
\text { rate per ET }\end{array}$ & $\begin{array}{c}\text { Delivery rate } \\
\text { per ET }\end{array}$ \\
\hline OD & 4882 & $51.9 \%$ & $37.1 \%$ \\
\hline FET & 6909 & $35.2 \%$ & $23.6 \%$ \\
\hline OD (FET) & 1376 & $35.8 \%$ & $24.3 \%$ \\
\hline
\end{tabular}

Age of women undergoing ART procedures and delivery rate

The mean age of women undergoing IVF/ICSI was 36 years (SD 4.7). Figure 1 shows the age distribution of women undergoing IVF/ICSI. Thirty six percent of initiated cycles were in women aged $\leq 34$ years; $38 \%$ in women aged 35 through 39 years; $17 \%$ in women aged 40 through 42 years; and $8 \%$ in women aged $\geq 43$ years. Thus, $25 \%$ of women undergoing IVF/ICSI were $\geq 40$ years.

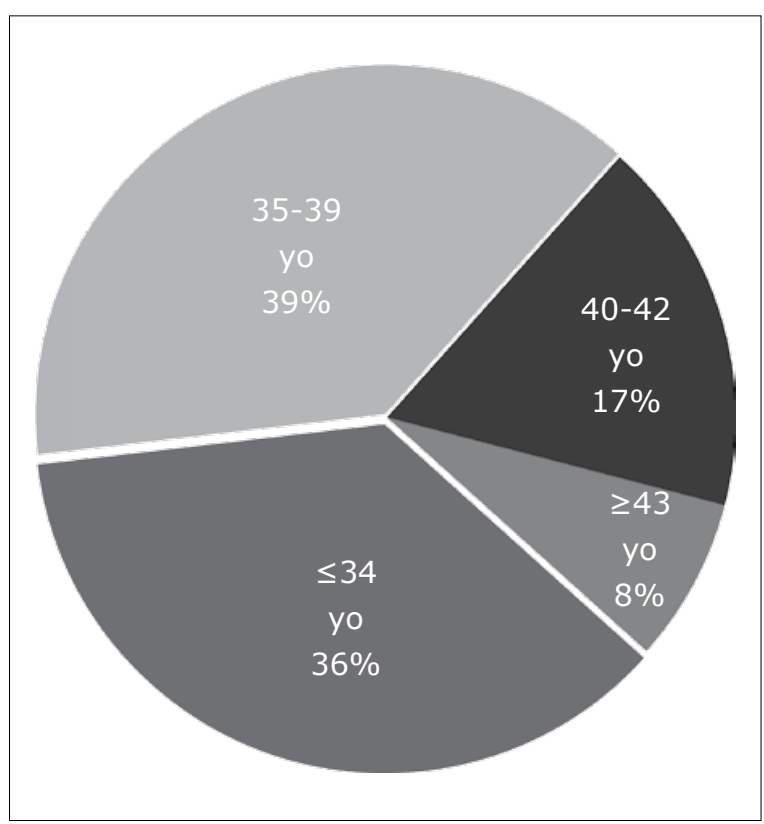

Figure 1. Age distribution of women undergoing IVF/ICSI, 2011

As expected, the delivery rate per embryo transfer in autologous reproduction was significantly influenced by the age of the female partner. We analyzed DR/ET in the following age categories: women aged $\leq 34$ years; women aged 35 through 39 years; women aged 40 through 42 years; and women aged $\geq 43$ years. DR decreased with the age of the woman, from $32.8 \%$ in the younger women to $7.6 \%$ in the oldest group $(p<0.001)$ (Fig. $2 a$ and $2 b)$.

In an oocyte donation program, the age of oocyte recipients seems to affect the outcome of treatment. The DR/ET in oocyte recipients aged $\leq 34$ years $(n=449 E T)$ was $41.2 \%$.; in women aged 35 through 39 it was $41.4 \%$ ( $n=1,035$ embryo transfers); in women aged 40 through 42 it was $36.6 \%$ ( $n=1,196$ embryo transfers); and in women aged $\geq 43$ years old it was $34.2 \%(n=2,22$ embryo transfers $)(p<0.0001)$.

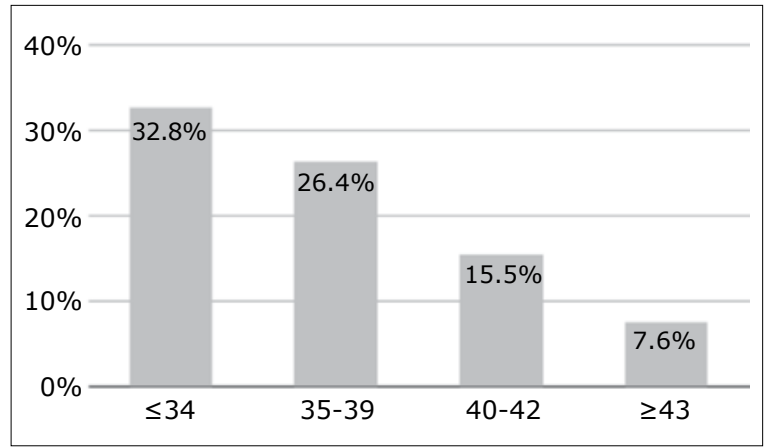

Figure 2a. Delivery rate per embryo transfer in different age categories of women undergoing IVF/ICSI, 2011

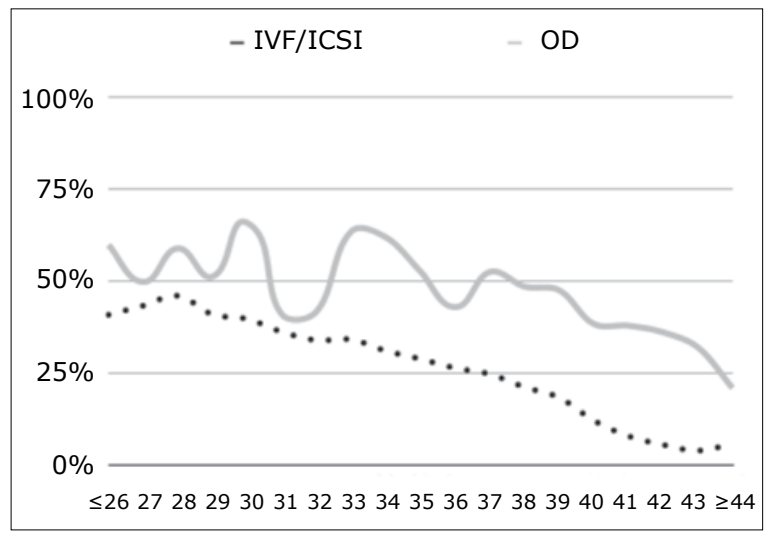

Figure 2b. Delivery rate per embryo transfer according to age of woman, 2011

\section{Number of embryos transferred and multiple deliveries} Autologous reproduction

Table 3 shows the outcome of 21, 524 IVF/ICSI embryo transfers. The mean number of embryos transferred was 2.2 , lower than in the previous report (2.4). In $54.6 \%$ of cases, two embryos were transferred, and the transfer of 3 and $\geq 4$ embryos represented $27.3 \%$ and $4.3 \%$ respectively. The overall proportion of multiple delivery was $22.3 \%$, of which, $21.0 \%$ were twins and $1.3 \%$ triplets and higher, very similar to 2010 , when they were $22.1 \%$ and $1.8 \%$ respectively.

The risk of twin delivery increased with the transfer of $\geq 2$ embryos. The risk of twin deliveries was $22.4 \%$ when two embryos were transferred. This condition was not increased after the transfer of three ( $R R=1.00 ; 95 \% C I 0.90-1.12)$, or $\geq$ four embryos (RR $0.74 ; 95 \%$ CI $0.53-1.04$ ). However, the risk of triplet-and-higher order delivery increased significantly with the number of embryos transferred. When only one embryo was transferred, there were no triplets; when two embryos were transferred the rate of triplets-and-higher delivery was $0.3 \%$; when three embryos were transferred, the rate of triplets-and-higher delivery increased to $3.5 \%$; with a further increase to $3.9 \%(p<0.001)$, when $\geq 4$ embryos were transferred 
Heterologous reproduction (OD)

Table 4 shows the outcome of 4,863 transfer cycles with OD. The mean number of embryos transferred was 2.3 (in 2010 it was 2.4). In the majority of cases, two embryos were transferred $(61.4 \%)$, and the transfer of $\geq 3$-embryos represented $30.4 \%$ of the cases. The overall proportion of multiple births was $30.1 \% ; 28.5 \%$ were twin delivery, and $1.6 \%$ triplets and higher, compared with $25.4 \%$ and $2.2 \%$ in 2010 .

When compared with the transfer of two embryos, the transfer of three embryos increased the relative risk for twins to 1.3 (95\%CI $1.08-1.45)$.

The relative risk of triplet and higher order delivery increased significantly with the transfer of more than two embryos. The rate of triplets when 2,3 and $\geq 4$ embryos were transferred were $0.3 \%, 4.1 \%$ y $2.7 \%(p<0.001)$, respectively.

Frozen/thawed embryo transfers (FET)

Table 5 shows 6,899 cases of FET. The mean number of embryos transferred was 2.2 . Two embryos were transferred in $55.5 \%$ of cases $(61 \%$ in 2010$)$. The rate of multiple births was $19.2 \%$; where $17.8 \%$ were twin delivery $(17.6 \%$ in 2010$)$; and $1.4 \%$ triplets-and-high order delivery (1.5\% in 2010). The increase in the rate of multiple-delivery was less profound than in the previous techniques. The rate of triplets-and-higher delivery when one, two, three and $\geq$ four embryos were transferred was $0.0 \%, 0.5 \%, 3.4 \%$ and $3.8 \%$ respectively $(p<0.001)$.

Table 6 shows 1,375 cases of FET with donated oocytes. The mean number of embryos transferred was 2.3. Multiple- -delivery rate was $21.6 \%: 20.1 \%$ twins and $1.5 \%$ triplets. The risk of multiple-births also increased with the number of transferred embryos, however, this was less accentuated than in the case of fresh transfers $(p=0.034)$.

Elective singe and dual embryo transfer (eSET \& eDET) Elective single embryo transfer (eSET) and elective dual embryo transfer (eDET) accounted for 3.0\% $(n=635)$ and $26.1 \%(n=5,608)$ respectively, of embryo transfers performed in 2011. This represents an important increase to the previous register, when they represented $3.8 \%$ and $23.6 \%$, respectively. The DR/ET was $19.8 \%$ with eSET and $35.8 \%$ with eDET, values significantly better than non-elective SET(10.1\% $\mathrm{DR}, \mathrm{p}<0.0001)$, and DET $(23.5 \%, \mathrm{p}<0.0001)$.

In women aged $\leq 34$ years the DR of eSET and eDET were $29.6 \%$ and $39.5 \%$, respectively $(p<0.0001)$. In OD cycles, the DR/ET with eSET was $25.0 \%$, and $38.1 \%$ with eDET.

\section{Perinatal outcome}

The duration of gestation was reported in 8,182 deliveries $(6,253$ singletons, 1,820 twins, and $109 \geq$ triplets $)$. Among singletons, the mean gestational age at delivery was 37 weeks amenorrhea (WA); among twin it was 34 WA; and among $\geq$ triplets it was 32 WA $(p<0.001)$.

The risk of preterm birth, i.e. before completing 37 WA, among singletons was $18 \%(n=1,135)$. The relative risk of preterm birth among twin deliveries was 3.64 (95\% CI 3.42-3.88), and among triplets-and-higher was 5.20 (95\% CI 4.85-5.57). The

Table 3. Clinical pregnancy rate, delivery rate and gestational order according to the number of embryos transferred, IVF/ICSI 2011

\begin{tabular}{ccccccccc}
\hline \multirow{2}{*}{ Number of transferred embryos } & \multicolumn{2}{c}{ Total ET } & \multirow{2}{*}{ CPR/ET } & \multicolumn{4}{c}{ Deliveries } \\
\cline { 2 - 3 } & Number & $\%$ & & $\begin{array}{c}\text { Total } \\
\text { (number) }\end{array}$ & Singleton & Twin & $\geq$ Triplets \\
\hline 1 & 2980 & $13.8 \%$ & $19.5 \%$ & 362 & $97.5 \%$ & $2.5 \%$ & $0 \%$ \\
\hline 2 & 11753 & $54.6 \%$ & $40.7 \%$ & 3440 & $77.2 \%$ & $22.4 \%$ & $0.3 \%$ \\
\hline 3 & 5871 & $27.3 \%$ & $40.4 \%$ & 1623 & $74.0 \%$ & $22.6 \%$ & $3.5 \%$ \\
\hline$\geq 4$ & 920 & $4.3 \%$ & $34.1 \%$ & 179 & $79.3 \%$ & $16.8 \%$ & $3.9 \%$ \\
\hline Total & 21524 & $100.0 \%$ & $37.4 \%$ & 5,604 & $77.7 \%$ & $21.0 \%$ & $1.3 \%$ \\
\hline
\end{tabular}

$\mathrm{ET}=$ embryo transfers

$\mathrm{CPR}=$ clinical pregnancy rate

Table 4. Clinical pregnancy rate, delivery rate and gestational order according to the number of embryos transferred, OD 2011

\begin{tabular}{|c|c|c|c|c|c|c|c|}
\hline \multirow[b]{2}{*}{ Number of transferred embryos } & \multicolumn{2}{|c|}{ Total ET } & \multirow[b]{2}{*}{ CPR/ET } & \multicolumn{4}{|c|}{ Deliveries } \\
\hline & Number & $\%$ & & $\begin{array}{c}\text { Total } \\
\text { (number) }\end{array}$ & Singleton & Twin & $\geq$ Triplets \\
\hline 1 & 246 & $5.1 \%$ & $38.6 \%$ & 66 & $93.9 \%$ & $6.1 \%$ & 0 \\
\hline 2 & 2984 & $61.4 \%$ & $52.3 \%$ & 1117 & $72.3 \%$ & $27.4 \%$ & $0.3 \%$ \\
\hline 3 & 1476 & $30.4 \%$ & $55.1 \%$ & 584 & $61.6 \%$ & $34.3 \%$ & $4.1 \%$ \\
\hline$\geq 4$ & 157 & $3.2 \%$ & $39.5 \%$ & 37 & $83.8 \%$ & $13.5 \%$ & $2.7 \%$ \\
\hline Total & 4863 & $100.0 \%$ & $51.9 \%$ & 1804 & $69.9 \%$ & $28.5 \%$ & $1.6 \%$ \\
\hline
\end{tabular}

ET $=$ embryo transfers

$\mathrm{CPR}=$ clinical pregnancy rate

Table 5. Clinical pregnancy rate, delivery rate and gestational order according to the number of embryos transferred, FET 2011

\begin{tabular}{cccccccc}
\hline \multirow{2}{*}{ Number of transferred embryos } & \multirow{2}{*}{ Total ET } & \multirow{2}{*}{ CPR/ET } & \multicolumn{5}{c}{ Deliveries } \\
\cline { 4 - 8 } & & & $\begin{array}{c}\text { Total } \\
\text { (number) }\end{array}$ & Singleton & Twin & $\geq$ Triplets \\
\hline 1 & 1019 & $14.8 \%$ & 158 & $98.1 \%$ & $1.9 \%$ & $0.0 \%$ \\
\hline 2 & 3831 & $55.5 \%$ & 980 & $81.3 \%$ & $18.2 \%$ & $0.5 \%$ \\
\hline 3 & 1830 & $26.5 \%$ & 436 & $74.1 \%$ & $22.5 \%$ & $3.4 \%$ \\
\hline$\geq 4$ & 219 & $3.2 \%$ & 53 & $75.4 \%$ & $20.8 \%$ & $3.8 \%$ \\
\hline Total & 6899 & $100.0 \%$ & 1627 & $80.8 \%$ & $17.8 \%$ & $1.4 \%$ \\
\hline
\end{tabular}

ET= embryo transfers

$\mathrm{CPR}=$ clinical pregnancy rate 
risk of very-preterm birth, i.e. before completing 32 WA, among singletons was $5.0 \%(n=309)$; among twins it was $9.9 \% \%$ $(n=179)$ and among $\geq$ triplets it was $23.2 \%(n=26)(p<0.0001)$. Table 7 shows that the perinatal mortality increased significantly with gestational order. Singletons had a perinatal mortality of 9.3 per thousand, compared with 15.1 per thousand in twins and 21.6 per thousands in $\geq$ triplets $(p<0.0001)$. The RR of perinatal mortality among twins was 1.6 (95\% CI 1.14-2.29), and among triplets-and-higher was 2.3 (95\% CI 1.12-4.80).

\section{Miscarriage rate}

The miscarriage rate in women undergoing IVF/ICSI was $17.1 \%$, which increased significantly with the age of the woman. The miscarriage rate was $14.3 \%$ in women aged $\leq 34 ; 17.1 \%$ in women aged 35 through 39 years; $24.1 \%$ in women aged 40 through 42 ; and $32.5 \%$ in women aged 43 years $(p<0.001)$. Within each age category, the miscarriage rate did not differ significantly in women having PGD, however, the characteristic of women in each category might be different and therefore, not comparable.

The miscarriage rate in women undergoing OD was $16.3 \%$, and there were no significant differences according to age categories. Thirteen percent in women aged $\leq 34$ years; $11.8 \%$ in women aged 35 through 39 years; $17.4 \%$ in women aged $40-42$ and $18.1 \%$ in women aged $\geq 43$ years $(p=0.010)$. The miscarriage rate in women undergoing FET was $20.5 \%$. No subgroup analysis was performed in this case, since the RLA reports the age of the woman at the time of embryo transfer not at the time of embryo freezing.

\section{Pre implantation Genetic Diagnosis (PGD)}

Centers in Argentina, Brazil, Chile, Mexico, Peru and Venezuela reported 1,028 cycles with PGD, from which 534 embryo transfers were performed. The mean age of women undergoing embryo transfer after PGD was 36 years ( 23 to 52 years). A mean of six embryos were analyzed in each cycle, and a mean of two of each were reported as normal. Two hundred and three clinical pregnancies were registered and 153 deliveries (129 singletons, 24 twins). A total of 177 babies were born after PGD, none of which were reported with any birth defect.

Assisted hatching $(A H)$

Institutions in Argentina, Brazil, Chile, Mexico and Peru reported 3,595 cycles with $\mathrm{AH}$. In total, 3,220 embryo transfer cycles, generating 952 clinical pregnancies and 633 deliveries $(31.3 \%)$. Of these, 507 were reported as singletons, 116 twins and 10 triplets. The mean age of the women undergoing assisted hatching was 36 years ( $S D=4$ years).

Intrauterine insemination

Table 8 shows the results of IUI cycles, reported by clinics located in nine different countries, either with semen of the husband (IIU-H) or donor (IIU-D),

One hundred and twenty three clinics reported 6,172 cycles of IIU-H. The delivery rate per cycles was $13.7 \%$. The multiple-delivery rate was $13.4 \%$ : $11.7 \%$ twin and $1.7 \%$ triplets-and-higher.

One hundred and three clinics reported 1092 cycles of IIU-D. The delivery rate per cycles was higher, $18.4 \%$. The multiple-delivery rate was $10.3 \%: 9.3 \%$ twin and $1.0 \%$ triplets-and-higher.

\section{Cumulative/total delivery rate}

The cumulative delivery rate corresponds to the number of deliveries resulting from one initiated or aspirated ART cycle including the cycle when fresh embryos are transferred, and subsequent frozen/thawed ART cycles. This rate is used when less than the total numbers of embryos fresh and/or frozen/thawed have been utilized from one ART cycles. If all embryos are used, it is referred to as total delivery rate. Cumulative deliveries are calculated by adding deliveries derived from fresh plus frozen transfers. In future years, it will be possible to calculate cumulative events by each person. So far, cumulative delivery rates in Latin America is $27.8 \%$, the same as in 2010 (28.0\%) (Table9)

\section{Complications}

Clinics reported 81 cases of ovarian hyper stimulation syndrome, corresponding to a rate of $0.3 \%$. Other less frequent complications included eight cases of hemorrhage and one case of infection. It is likely that there is a sub-registry of complications.

\section{DISCUSSION}

This is the twenty-third version of RLA, which has been published continuously since 1990 , covering the majority of ART procedures performed in LA. Over these twenty years, the RLA has evolved, including the recollection and analysis of more and more complex information, and allowing the readers to download the registry in PDF file from our web page (www.redlara.com).

Starting with the 2010-register, we have implemented an individualized case-by-case register, and thus the RLA beca-

Table 6. Clinical pregnancy rate, delivery rate and gestational order according to the number of embryos transferred, FET(OD) 2011

\begin{tabular}{cccccccccc}
\hline \multirow{2}{*}{ Number of transferred embryos } & \multicolumn{2}{c}{ Total ET } & \multirow{2}{*}{ CPR/ET } & \multicolumn{4}{c}{ Deliveries } \\
\cline { 2 - 5 } & Number & $\%$ & & $\begin{array}{c}\text { Total } \\
\text { (number) }\end{array}$ & Singleton & Twin & $\geq$ Triplets \\
\hline 1 & 148 & $10.8 \%$ & $29.7 \%$ & 24 & $95.8 \%$ & $4.2 \%$ & $0.0 \%$ \\
\hline 2 & 753 & $54.8 \%$ & $36.5 \%$ & 188 & $75.5 \%$ & $25.0 \%$ & $0.5 \%$ \\
\hline 3 & 428 & $31.1 \%$ & $37.9 \%$ & 113 & $80.5 \%$ & $16.8 \%$ & $2.7 \%$ \\
\hline$\geq 4$ & 46 & $3.3 \%$ & $23.9 \%$ & 9 & $88.9 \%$ & $0.0 \%$ & $11.1 \%$ \\
\hline Total & 1375 & $100.0 \%$ & $35.8 \%$ & 334 & $78.4 \%$ & $20.1 \%$ & $1.5 \%$ \\
\hline
\end{tabular}

$\mathrm{ET}=$ embryo transfers

$\mathrm{CPR}=$ clinical pregnancy rate

Table 7. Perinatal mortality according to gestational order, 2011

\begin{tabular}{|c|c|c|c|c|c|c|c|c|c|}
\hline & \multicolumn{3}{|c|}{ Singleton } & \multicolumn{3}{|c|}{ Twin } & \multicolumn{3}{|c|}{$\geq$ Triplets } \\
\hline & LB & SB & ND & LB & SB & ND & LB & SB & ND \\
\hline IVF/ICSI & 4323 & 11 & 12 & 2298 & 4 & 21 & 209 & 3 & 3 \\
\hline FET & 1297 & 19 & 8 & 560 & 2 & 3 & 63 & 0 & 0 \\
\hline OD & 1249 & 5 & 7 & 996 & 5 & 19 & 75 & 0 & 2 \\
\hline FET (OD) & 257 & 3 & 2 & 127 & 5 & 2 & 15 & 0 & 0 \\
\hline Total & 7126 & 38 & 29 & 3981 & 16 & 45 & 362 & 3 & 5 \\
\hline $\begin{array}{l}\text { Perinatal } \\
\text { mortality (*) }\end{array}$ & \multicolumn{3}{|c|}{9.3} & \multicolumn{3}{|c|}{15.1} & \multicolumn{3}{|c|}{21.6} \\
\hline
\end{tabular}

$\mathrm{LB}=$ live borns; $\mathrm{SB}=$ still borns; $\mathrm{ND}=$ neonatal death; $\left(^{*}\right)$ per 1,000 
Table 8. Intrauterine insemination 2011

\begin{tabular}{llcccc}
\hline \multirow{2}{*}{ IUI } & \multirow{2}{*}{ Cycles } & \multirow{2}{*}{$\begin{array}{c}\text { Deliveries/ } \\
\text { cycles }\end{array}$} & \multicolumn{3}{c}{ Gestational order } \\
\cline { 4 - 6 } & & Singleton & Twin & $\geq$ Triplets \\
\hline Husband & 6172 & $\begin{array}{c}13.7 \% \\
(843 / 6172)\end{array}$ & $88.9 \%$ & $11.7 \%$ & $1.7 \%$ \\
\hline Donor & 1092 & $\begin{array}{c}18.4 \% \\
(201 / 1092)\end{array}$ & $89.7 \%$ & $9.3 \%$ & $1.0 \%$ \\
\hline
\end{tabular}

Table 9. Cumulative delivery rate IVF/ICSI, 2011

\begin{tabular}{lcc}
\hline & $(\mathbf{n})$ & $\begin{array}{c}\text { Delivery rate } \\
\text { per OPU }\end{array}$ \\
\hline Total OPU & 26,321 & $\mathrm{NC}$ \\
\hline Deliveries IVF/ICSI & 5623 & $21.4 \%$ \\
\hline Deliveries FET & 1628 & $6.2 \%$ \\
\hline Cumulative delivery & \multicolumn{2}{c}{$27.5 \%$} \\
\hline
\end{tabular}

me the first and only multinational case-by-case registry. The software used was developed by RLA, and was field-tested in several institutions in the region. In order to implement this new method, workshops were carried out in different countries, and we believe, that the program is still in a developmental phase and continuous check-in systems are being incorporated as problems arise during its implementation. One of the main strength of the RLA is the uniformity of terminology. All clinics reporting to RLA, use the glossary defined in 2009 by the International Committee for Monitoring Assisted Reproductive Technologies (ICMART) and the World Health Organization (WHO) (Zegers-Hochschild, Nygren at al, 2006; Zegers-Hochschild, Adamson et al, 2009). The other strength is that the data voluntarily reported by each center, is periodically checked by an external and independent accreditation team, composed by a clinician and a embryologist.

In 2011, 145 clinics from twelve countries reported 41,232 ART cycles. This represents an increase of $9 \%$ compared with 2010 The use of ICSI instead of conventional IVF continues to increase. In 2011 ICSI represented $86 \%$ of oocyte pick-ups, similar to $2010(86 \%), 2009$ and 2008(85\%).

The age of women undergoing IVF/ICSI cycles continues to increase. In 2011, the proportion of IVF/ICSI cycles performed in women aged 35 through 39 reached $38 \%$ of cycles; and $25 \%$ of women were $\geq 40$ years. Furthermore, $8 \%$ of IVF/ICSI cycles were performed in women aged $\geq 43$ years. Since the age of the woman is one of the most important prognosis factors, this demographic reality is important to consider when analyzing regional outcomes.

The delivery rate per oocyte pick-up in IVF/ICSI reached $21.4 \%(23.4 \%$ in 2010$)$, and the cumulative delivery rate reached $27.5 \%$.

The mean number of transferred embryos in IVF/ICSI decreased from 2.4 (2010) to 2.2 in the actual report. The proportion of ET corresponding to eSET dropped from $3.8 \%$ in 2010 to 3.0 in 2011; however, the proportion and ET corresponding to eDET increase from $23.6 \%$ to 26.1 . It is still worrisome that in one third of ET more than three embryos were transferred, and in $4 \%$, more than four embryos were transferred.

Both in IVF/ICSI and OD cycles, the transfer of more embryos resulted in an increase in the risk of triplets-and-higher order deliveries. Interestingly, the increase in the risk of twin-deliveries was marginal, and barely reached statistical significance. Thus, $22 \%$ of deliveries in IVF/ICSI cycles were multiple $(1.3 \%$ triplets-and-higher), and $30 \%$ of deliveries in OD cycles were multiple (1.6\% triplets and higher). Increasing the number of ET above two, does not significantly impact delivery rates nor twin rates. What it does, is increase the high order multiples which are so detrimental for perinatal mortality and morbidity. As shown in this as well as previous reports, even twin deliveries increase the risk of preterm birth and perinatal mortality. And as discussed previously, the transfer of $\geq$ two embryos is associated to an increase in the risk of multiple delivery. Probably, the main reason to transfer more embryos is the desire of both clinicians and patients to improve the outcome of each
ART cycle, without considering the risk of multiple deliveries and associated prematurity. The data showed in this report is quite reassuring, since the results associated with eSET and eDET, especially in younger patients undergoing IVF/ICSI, and OD cycles, are higher than reported in previous reports.

Since the present report correspond to the analysis of observational data, and not the results of properly designed controlled trials, the results cannot be considered as a evidence or support for a decreased benefit in some procedures. For example, PGD was not associated with neither a significant increase in the delivery rate nor a reduction in the miscarriage rate. This might be explained by the fact, that the number of procedures is still low and RLA does not register differently pre-natal genetic diagnosis and pre-natal screening. Furthermore, the selection of women having PGD can be very different to the rest of the population, even when stratified by age. On the other hand, assisted hatching does not increase delivery rate, since no statistical significance was reached, however, caution must be expressed when analyzing this data. The frequency of complications associated to ART procedures was rather low, only 90 cases of OHSS were reported, which represented a risk of $0.3 \%$ of initiated cycles. Furthermore, only eight cases of genital hemorrhage and one case of infections were reported. Nevertheless, this low frequency might represent a recollection bias, that needs to be improved.

This is the fifth report of IUI cycles. Clinics reported 6,172 IUI with husband's semen, and 1,092 cycles with donor's semen. This represent an important increase compared to 2010 , when 4,874 IUI-H and 876 IUI-D were reported. However, this is far from the data reported in 2009, when 13,410 IIU-H and 2,430 IIU-D cycles were reported. This might be explained by the labor-consuming work that represented the change into a case-by-case register.

In summary, this is the second case-by-case register published by the RLA. It is reassuring for patients and clinics that the results of ART procedures performed in the region are similar or even better than in most European and Asian countries (Nygren et al, 2011; Ferraretti et al, 2012)). However, REDLARA has to enforce the reduction in the number of embryos transferred in IVF/ ICSI and OD cycles, in order to prevent multiple births, or at least, high order multiples and decrease the corresponding perinatal complications.

\section{Corresponding Author}

Oficina del Registro LatinoAmericano Reproducción

Lo Fontecilla 441, Santiago, Chile.

Teléfono: 56-2-6108181 / Fax: 56-2-6108167

E-mail: registro@redlara.com

\section{REFERENCES}

Ferraretti AP, Goossens V, de Mouzon J, Bhattacharya S, Castilla JA, Korsak V, et al. Assisted reproductive technology in Europe, 2008: results generated from European registers by ESHRE. Hum Reprod. 2012, Sep;27(9):2571-2584.

Nygren KG, Sullivan E, Zegers-Hochschild F, Mansour R, Ishihara $\mathrm{O}$, Adamson GD, and de Mouzon J. International Committee for Monitoring Assisted Reproductive Technology (ICMART) world report: assisted reproductive technology 2003. Fertil Steril. 2011, Jun;95(7):2209-22, 2222.e1-17.

Zegers-Hochschild F, Nygren KG, Adamson GD, de Mouzon J, Lancaster $\mathrm{P}$, Mansour $\mathrm{R}$, et al. The International Committee Monitoring Assisted Reproductive Technologies (ICMART) glossary on ART terminology. Fertil Steril. 2006, Jul;86(1):16-9.

Zegers-Hochschild F, Adamson GD, de Mouzon J, Ishihara O, Mansour $\mathrm{R}$, Nygren $\mathrm{K}$, et al. The International Committee for Monitoring Assisted Reproductive Technology (ICMART) and the World Health Organization (WHO) Revised Glossary on ART Terminology, 2009. Hum Reprod. 2009, Nov;24(11):2683-7.

\section{ANNEX I PARTICIPATING INSTITUTIONS}

\section{ARGENTINA}

Bariloche

1. Centro de Medicina Reproductiva Bariloche 
Buenos Aires

1. Centro de estudios en Ginecología y Reproducción (CEGYR)

2. Centro de Salud Reproductiva (CER)

3. Centro de Investigaciones en Medicina Reproductiva CIMER

4. FECUNDITAS

5. Centro especializado en tratamientos para la mujer-GENS

6. Hospital de Clínicas

7. Centro de Reproducción-Servicio de Ginecología-Hospital Italiano

8. HALITUS, Instituto Médico

9. PREGNA, Medicina reproductiva

10. Procrearte

11. Fertilidad San Isidro

12. SEREMAS

13. FERTILAB

Córdova

1. Centro Integral de Ginecología, Obstetricia y Reproducción (CIGOR)

2. FECUNDART

3. NASCENTIS, Medicina Reproductiva $(*)$

La Plata

1. Centro de Reproducción

Mar del Plata

1. Centro de estudios en Reproducción y Procedimientos de Fertilización Asistida (CRECER)

Mendoza

1. Centro de estudios en Reproducción Humana (CERH)

2. Instituto de Medicina Reproductiva

Rosario

1. Instituto de Fertilidad Asistida Dr Colabianchi

Salta

1. MATER Medicina Reproductiva

2. SARESA, Salud Reproductiva Salta

San Martín

1. PREFER, Instituto Médico de Ginecología y Fertilidad

BRASIL

Belo Horizonte

1. Instituto de Saúde Mulher

2. Clínica ORIGEN

3. Clínica Pro-criar/Mater Dei

Brasilia

1. Instituto Verhum - Video Endoscopia e Reproduçao Humana

2. GÊNESIS - Centro de Assistência em Reproduçao Humana Ltda.

3. Centro de Ensino e Pesquisa em Reproducao Assistida (CEPRA)

Campo Grande-Mato Grosso

1. Fertility Centro de Fertilização Humana Assistida de Campo Grande

Campinas-SP

1. Centro de Reprodução Humana de Campinas

2. Clínica Androfert

Cuiabá-Mato Grosso

1. Instituto Pérola de Reprodução Humana

2. LIFE Reproducción Humana

Curitiba

1. ANDROLAB - Clínica e Laboratorio de Andrología

2. CONCEBER, Centro de Medicina Reproductiva

3. Clínica FERTWAY

4. FELICCITA, Instituto de Fertilidade Itda

Fortaleza

1. BIOS - Centro de Medicina Reprodutiva
2. CONCEPTUS - Centro de Reprodução Humana do Ceará

Goiania Goiás

1. Fértile Diagnósticos - Reprodução Humana

2. Centro de Reprodução asistida FEMINA

Londrina-Paraná

1. CEDILON Serviços Médicos S.C. Ltda.

Paso Fundo

1. GÉNESIS - Clínica de Reprodução Humana

Porto Alegre

1. Centro de Reprodução Humana Nilo Frantz

2. FERTILITAT - Centro de Medicina Reprodutiva

3. INSEMINE - Centro de Reprodução Humana

4. Núcleo de Reprodução Humana do Hospital Moínhos de Vento GERAR

Recife - Pernambuco

1. NASCER Medicina Reprodutiva

2. Clínica de Fertilidade GERAR

Ribeirao Preto - SP

1. Centro de Reprodução Humana Prof. Franco Junior

2. Clinica Matrix

3. Laboratorio de Reprodução Humana, Hospital das Clínicas de Ribeirao Preto

Rio de Janeiro

1. Centro de Fertilidade Rede D'Or-

2. Clínica Origen

3. Clinica Pró Nascer

4. FERTIPRAXIS

5. Primordia

Salvador - Bahía

1. Centro de Reprodução Humana, Endoscopia e Medicina Fetal

Sao José Dos Campos - SP

1. Clínica REPROFERTY

2. Embryolife-Instituto de Medicina Reprodutiva

Sao José do Rio Preto

1. IMR - Centro Instituto de Medicina Reprodutiva e Fetal

2. Centro de Reprodução Humana de Sao Jose de Rio Preto

Sao Paulo - SP

1. Centro de Reprodução Humana FERTIVITRO Ltda.

2. ORIGINARE, Centro de Investigação em Reprodução Humana

3. Centro de Reprodução Humana Monteleone

4. CEERH - Centro Especializado em Reprodução Humana

5. FERTILITY - Centro de Fertilização Assistida

6. FERTICLIN - Clínica de Fertilidade Humana

7. Chedid Grieco Medicina Reprodutiva

8. HUNTINGTON - Centro de Medicina Reprodutiva

9. Serviço de Reprodução Humana, Hospital e Maternidade Santa Joana

Uberlandia - Minas Gerais

1. FECUNDA - Instituto de Reprodução Humana

Vitória

1. Jules White Medicina Reproductiva (anteriormente, "HUNTINGTON - Centro de Medicina deproductiva")

Santos

1. Clínica PRO GENESIS

Presidente Prudente

1. REPRODUCTION, Clínica Urológica e Centro de Reproducao Humana LTDA.

Contagem

1. Clinica Fertibaby $(*)$ 


\section{CHILE}

Santiago

1. Centro de estudios Reproductivos (CER)

2. Unidad de Medicina reproductiva, Clinica Alemana

3. Unidad de Medicina Reproductiva, Clinica las Condes

4. Unidad de Medicina Reproductiva, Clinica Monteblanco

5. Programa de Fertilización Asistida I.D.I.M.I.

Viña del Mar

1. Unidad de Medicina reproductiva, Clinica de la Mujer

Concepción

1. Centro de Fertilidad y Medicina Reproductiva CONCEPCION S.A.

\section{COLOMBIA}

Cali

1. Centro FECUNDAR Cali

2. Centro Médico IMBANACO

Bogotá

1. Unidad de Fertilidad del Couytry Ltda

2. Asociados en Fertilidad Humana

3. PROFAMILIA-Fertil

4. Unidad de Fertilidad, Procreación Médicamente Asistida

5. Instituto de fertilidad humana S.A.S. (INSER) $(*)$

Medellín

1. IN SER, Instituto Antioqueño de Reproducción

Barranquilla

1. PROCREAR

\section{ECUADOR}

Quito

1. Centro Ecuatoriano de Reproducción Humana

2. CONCEBIR, Unidad de Fertilidad y esterilidad

Guayaquil

1. Instituto Nacional de Investigación de Fertilidad Esterilidad (INNAIFEST)

2. Unidad de Fertilidad Hospital Alcivar

Cuenca

1. Clinica de Medicina Reproductiva BIOGEPA

\section{GUATEMALA}

1. Centro de Reproducción humana S.A.

\section{MEXICO}

Guadalajara - Jalisco

1. Centro de Reproducción Asistida del Occidente

2. Instituto de Medicina Reproductiva del Bajío (IMER)

3. Instituto de Ciencias en Reproducción humana

León - Guanajuato

1. Instituto de Ciencias en Reproducción Humana - VIDA

Matamoros

1. Instituto de Ciencias en Reproducción Humana - VIDA

México DF

1. Centro Especializado en Esterilidad y Reproducción Humana

2. INGENES

3. Centro Médico Nacional 20 de Noviembre

4. Centro de Reproducción Asistida del Hospital Español

5. Instituto Médico de la Mujer

6. Instituto Mexicano de alta tecnología reproductiva S.C.

7. Centro especializado para la atención de la mujer

8. Instituto Valenciano de Infertilidad (IVI)

9. Clinica de Biología de la Reproducción

10. Embryos Polanco SA de CV $(*)$

11. Biología de la Reproducción Humana, Cirugía reproductiva gin. Y obst. (INSEMER) $(*)$

12. Unidad de Medicina Reproductiva Hospital Angeles del Pedregal $(*)$
Monterrey, Nuevo León

1. Centro Universitario de Medicina Reproductiva, Universidad Autónoma de

2. Instituto para el Estudio de la Concepción Humana

3. Creasis SC

Puebla

1. Centro de Ginecología y Reproducción Asistida S.C. GYRA

Querétaro

1. Médica Fértil

San Luis de Potosí

1. Médica Fértil

2. Filius (anteriormente, OBGIN S.C., SLP)

Tijuana Baja California

1. Instituto de Medicina Reproductiva del Bajío - IMER

2. Instituto para el Estudio de la Concepción Humana de Baja California (IECH \& BC)

Veracruz

1. Centro de Diagnóstico Ginecológico

Saltillo

1. Centro de Reproducción asistida de Saltillo

Tampico

CEMAIN $(*)$

NICARAGUA

Managua

1. Centro de Fertilidad de Nicaragua, NICFERT

\section{PANAMA}

1. IVI, Panamá S.A.

PERÚ

Lima

1. Clínica CEFRA, Centro de fertilidad y Reproducción Asistida

2. Clínica Miraflores, Instituto de Ginecología y Fertilidad

3. Grupo PRANOR, Clinica Concebir

4. Grupo PRANOR, Instituto de Ginecología y reproducción.

5. FERTILAB $(*)$

URUGUAY

Montevideo

1. Centro de Esterilidad Montevideo (CEM)

2. Centro de Reproducción Humana del Interior

\section{VENEZUELA}

Caracas

1. FERTILAB, Clinica el Avila

2. UNIFERTES, Clínica el Avila

3. EMBRIOS, Centro de Fertilidad y Reproducción humana, Hospital de Clínicas Caracas

4. GENESIS, Unidad de Fertilidad y Reproducción

Valencia

1. Instituto Venezolano de Fertilidad

Maracaibo

1. Laboratorios In Vitro de Venezuela

Centros que reportaron fuera de plazo:

Nascer (Lima, Perú)

Progest (Porto Alegre, Brasil)

$\left.{ }^{*}\right)$ not yet fully accredited 